\title{
FROM EARTH TO HEAVEN: STATES' CRIMINAL JURISDICTION IN THE SPACE STATION
}

\author{
Rafika Shari'ah binti Mohd Hassan*
}

\begin{abstract}
State jurisdiction is a familiar aspect of international law. State jurisdiction could theoretically extend to outer space, and thus it may then be referred to as "Space Jurisdiction". A state's jurisdiction in outer space extends to its space objects and inhabitants. As crime on outer space is possible, therefore there is an uncertainty as to whether a state has the jurisdiction to try its nationals or foreign nationals who have committed an offense in outer space and in the space station. This paper aims to contribute to the existing body of knowledge and practice and, more importantly, guide the government agency, should they want to send astronauts to the space station in the future. It examines the legal regime regulating state jurisdiction in outer space in the context of the increasing commercialisation of outer space. This study draws significantly from international law statutes and the literature written by prominent jurists and scholars in space law. It finally offers some possible solutions to the gaps in the legal regime regulating state jurisdiction in outer space.
\end{abstract}

Keywords: international law, state jurisdiction, concurrent jurisdiction, outer space law, International Space Station.

Advocate \& Solicitor High Court of Malaya, Candidate Master of Laws (LLM), University Technology Mara (UITM). 


\title{
BIDANG KUASA JENAYAH NEGERI DALAM STESEN ANGKASA: SATU PENILAIAN KRITIKAL
}

\begin{abstract}
ABSTRAK
Bidangkuasa sesebuah Negara adalah satu aspek yang sangat penting di sisi undang-undang antarabangsa. Secara teori bidangkuasa kerajaan boleh dilanjutkan ke angkasa lepas, dan dikenali sebagai 'Bidangkuasa Angkasa Lepas'. Bidangkuasa sesebuah kerajaan di angkasa lepas meliputi objek ruang dan warganegara. Memandangkan terdapat kemungkinan bahawa jenayah boleh berlaku di ruang angkasa lepas, maka terdapat keraguan mengenai sama ada sesebuah negara mempunyai bidangkuasa untuk membicarakan rakyatnya atau terhadap warganegara asing yang telah melakukan suatu kesalahan di angkasa lepas dan di stesen angkasa. Kajian ini bertujuan untuk menambah pengetahuan serta amalan, dan yang lebih penting lagi, untuk memberi manafaat kepada agensi kerajaan, sekiranya kerajaan mahu menghantar angkasawan ke stesen angkasa lepas pada masa hadapan. Kajian ini juga mengkaji kerangka undang-undang yang mengawal selia bidangkuasa negara di angkasa lepas dalam konteks pengkomersialan di angkasa lepas yang semakin meningkat. Kajian ini telah merujuk terutamanya kepada undang-undang antarabangsa dan penerbitan yang ditulis oleh pakar yang terkemuka dalam undang-undang angkasa lepas. Akhirnya, kajian ini juga menawarkan beberapa kebarangkalian penyelesaian kepada kelompongan di dalam kerangka yang mengawal selia bidangkuasa undang-undang negara di angkasa lepas.
\end{abstract}

Kata kunci: undang-undang antarabangsa, bidangkuasa negara, bidangkuasa serentak, undang-undang angkasa lepas, Stesen Angkasa Antarabangsa.

\section{INTRODUCTION}

Space tourism is a relatively recent development. In 2001, Dennis Tito became the first space tourist to board the Russian shuttle and visit the International Space Station (ISS). Prior to Tito, only professionally trained astronauts could set their feet on the Moon and venture into the space vacuum. The commercial space odyssey did not just stop after Tito; it further allured more space enthusiasts. Among them, wealthy private individuals and private companies. Robert Bigelow, a billionaire 
and the Chief Executive Officer of Bigelow's Aerospace, developed a commercial space station attached to the ISS. He is currently planning to set up another station based on the moon. Evidently, space tourism is no longer a science fiction capturing our imagination, but is now becoming a reality. The ISS, with its initial objective to be the center for international scientific research and studies in outer space, has become another major attraction for commercial activities. Sattler found that the commercialisation of the ISS is due to the economic growth of the partner states of the ISS and the interests of private entities to participate in space activities. ${ }^{1}$

State jurisdiction is more important in international law than in domestic law. ${ }^{2}$ Apparently, in the context of outer space law, issues regarding state jurisdiction become more complex and challenging, especially if it involves two or more competing jurisdictions, i.e. concurrent jurisdictions. At first glance, States could invoke the International Space Law to remedy the space disputes that arise from competing jurisdictions, yet the Space Law itself contains sovereign limitation and some flaws. The foremost limitation is the extension of states' jurisdiction in the outer space. In respect of flaws, apart from the space law, treaties were concluded long before the era of space commercialisation. There is also the problem of absence of appropriate legal rules and principles to govern the commercialisation of space activities. $^{3}$

However, since the legal framework of space law itself is the product of the Public International Law, it embodies the principles of jurisdiction under international law. In this respect, it is pertinent to re-visit the notion of state jurisdiction in international law for a better understanding of the significance of state jurisdiction in the outer space and consequently its relation to the possibility of crimes occuring on the International Space Station.

\section{SPACE LAW}

The successful launch of Sputnik-1 by Russia on 4 September 1957 and Explorer 1 by the United States on 31 January 1958 raised a conflict

\footnotetext{
1 Rosanna Sattler, "US Commercial Activities Aboard the International Space Station," Air and Space Law 28, no. 2 (2003): 66-82.

2 Sidney B Jacoby, "Some Aspects of the Jurisdiction of the Permanent Court of International Justice," American Journal of International Law, 1936, 233-55. Frans von der Dunk, "Space Law in the Age of the International Space Station," Space and Telecommunications Law Program Faculty Publications, 2009, 6.
} 
between the two states in relation to the claim for sovereignty in outer space. ${ }^{4}$ The United Nations (UN) took certain initiatives to prevent the colonisation of outer space. ${ }^{5}$ Additionally, the General Assembly of the UN established the Committee on the Peaceful Uses of Outer Space (COPUOS) to govern the exploration and use of space for the benefit of all humanity: for peace, security and development. ${ }^{6}$ The COPUOS, created two sub-committees, the Legal Subcommittee ${ }^{7}$ and the Scientific Subcommittee. ${ }^{8}$ As a result, the UN has produced five international space treaties as follows:

1. The Treaty on Principles Governing the Activities of States in the Exploration and Use of Outer Space, including the Moon and Other Celestial Bodies (the Outer Space Treaty) $;{ }^{9}$

2. The Agreement on the Rescue of Astronauts, the Return of Astronauts and the Return of Objects Launched into Outer Space (the Rescue Agreement): ${ }^{10}$

3. The Convention on International Liability for Damage Caused

$4 \quad$ Nandasiri Jasentuliyana, International Space Law and the United Nations (Kluwer Law International, 1999), 22.

5 Jasentuliyana, International Space Law and the United Nations.

$6 \quad$ "Resolutions Adopted by the General Assembly- Outer Space Treaty," United Nations Office for Outer Space Affairs, accessed June 1, 2014, http://www. unoosa.org/oosa/en/ourwork/spacelaw/treaties/outerspacetreaty.html.

7 Ibid. The Legal Subcommittee meets every year for two weeks to discuss legal questions related to the exploration and use of outer space. Topics include the status and application of the five United Nations treaties on outer space, the definition and delimitation of outer space, national space legislation, legal mechanisms relating to space debris mitigation, and international mechanisms for cooperation in the peaceful exploration and use of outer space.

$8 \quad$ Ibid. The Scientific and Technical Subcommittee (STSC) meets every year for two weeks to discuss questions related to the scientific and technical aspects of space activities. Topics for discussion include space weather, near-Earth objects, the use of space technology for socioeconomic development, or for disaster management support, global navigation satellite systems, and the long-term sustainability of outer space activities.

9 "Status of International Agreements Relating to Activities in Outer Space," Committee on the Peaceful Uses of Outer Space Legal Subcommittee FiftyFourth Session (Vienna), accessed September 1, 2014, http://www.unoosa.org/ pdf/limited/c2/AC105_C2_2015_CRP08E.pdf. The treaty was open opened for signature on 27 January 1967 and entered into force on 10 October 1967. As at 1 January 2015, 103 States have ratified and 25 States have signed.

10 Ibid. The treaty was opened for signature on 22April 1968 and entered into force on 3 December 1968. As at 1 January 2015, 94 States have ratified, 24 States have signed and 2 States have acceded. 
by Space Objects (the Liability Convention): ${ }^{11}$

4. The Convention on Registration of Objects Launched into Outer Space (the Registration Convention); ${ }^{12}$ and

5. The Agreement Governing the Activities of States on the Moon and Other Celestial Bodies (the Moon Agreement). ${ }^{13}$

These five treaties were established to enhance international peace and security, promote international co-operation, as well as to enhance understanding among states. ${ }^{14}$ Jasentuliyana argued that space law is not perfect and complete, and must be reassessed and revised to reflect current developments in politics and technology. In particular, space law cannot foresee all of the potential problems faced by private entities, and requires clarification in order to address the complex issues that arise in the space industry. This is in line with the earlier research by Bin Cheng, which stated that the weaknesses of space law are due to the fact that it was formulated in the era before commercialisation of space activities began. ${ }^{15}$ Therefore, there is a necessity for space law to be improved to meet the complexity and current developments in space. This will assist those who are interested to participate in any space activities.

\section{JURISDICTION IN OUTER SPACE}

Jurisdiction is a vital feature of state sovereignty. Jurisdiction connotes the power of a state to submit its subjects and property to its national law and its municipal courts. ${ }^{16}$ A state may exercise its jurisdiction through three means; legislative, executive or judicial action. ${ }^{17}$ The principles

11 Ibid. The treaty was opened for signature on 1 September 1972, entered into force on 29 March 1972. As at 1 January 2015, 92 States have ratified, 21 States have signed, while 3 States have acceded to the treaty.

12 Ibid. The treaty was opened for signature at 14 January 1975 , entered into force in 15 September 1976. As at 1 January 2015, 62 States have ratified, while 4 States have signed and 3 States have acceeded to the treaty.

13 Ibid. The treaty was opened for signature on 18 December 1979, and entered into force on 11 July 1979. As at 1 January 2015, only 16 States have ratified while 4 States have signed.

14 Jasentuliyana, International Space Law and the United Nations, 22.

15 Bin Cheng, "International Law and High Altitude Flights: Balloons, Rockets and Man-Made Satellites," International and Comparative Law Quarterly 6, no. 03 (1957): 487-505.

16 Brownlie Ian, "Principles of Public International Law" (Oxford:-Oxford University Press, 2008), 299.

17 Ian, "Principles of Public International Law." 
of jurisdiction in outer space are the same principles of jurisdiction applicable on earth. To discuss the issue of state's jurisdiction in outer space, it is better to break the discussion into two core perspectives: first, state jurisdiction in outer space; and second, state's jurisdiction over a state's space objects and personnel.

\section{i. State Jurisdiction in Outer Space}

In respect of state jurisdiction in outer space, space law is very clear that no State is allowed to extend its sovereignty to the space areas. Article 2 of the Outer Space Treaty 1967 declared that the outer space is not subjected to any sovereign powers. ${ }^{18}$ According to article 11 of the Moon Agreement 1979, no state may claim national appropriation of the moon and other celestial bodies, either by a claim of sovereignty, occupation or by any other means. ${ }^{19}$ The Agreement further states that the moon and its natural resources are the common heritage of mankind..$^{20}$ Joyner examined the notion, aspects and legal implications of the 'Common Heritage of Mankind'21. The author found that under the 'common heritage of mankind', no State can claim its authority in the space areas. ${ }^{22}$ The author also found that the administration of the space areas shall be with the international community. In other words, space law clearly prohibits any state claiming sovereignty over parts of outer space, the moon and other celestial bodies. Furthermore, only the international community, has the power to govern and regulate the space activities. ${ }^{23}$

\section{ii. State's Jurisdiction Over a State's Space Objects and Personnel}

Though a State is prohibited from claiming sovereignty and jurisdiction in outer space, yet there are provisions under the space law that confer certain powers and rights to the States over their space objects and

18 See Article 2, Treaty on Principles Governing the Activities of States in the Exploration and Use of Outer Space, including the Moon and Other Celestial Bodies 1967.

19 See Article 11, Agreement Governing the Activities of States on the Moon and Other Celestial Bodies 1979.

20 Ibid.

21 Christopher C Joyner, "Legal Implications of the Concept of the Common Heritage of Mankind," International and Comparative Law Quarterly 35, no. 01 (1986): 190-99.

22 Ibid.

23 Ibid. 
personnels. Article 7 of the Outer Space Treaty 1967 states that: $^{24}$

A State on whose registry an object launched into outer space is carried shall retain jurisdiction and control over such object, and over any personnel thereof, while in outer space or on a celestial body. Ownership of objects launched into outer space, including objects landed or constructed on a celestial body, and of their component parts is not affected by their presence in outer space or on a celestial body or by their return to Earth. Such objects or component parts found beyond the limits of the State Party to the Treaty on whose registry they are carried shall be returned to that State Party, which shall, upon request, furnish an identifying date prior to their return.

Meanwhile, article 12(1) of the Moon Agreement 1979 reads: ${ }^{25}$

States Parties shall retain jurisdiction and control over their personnel, vehicles, equipment, facilities, stations and installations on the moon. The ownership of space vehicles, equipment, facilities, stations and installations shall not be affected by their presence on the moon.

Considering the provisions above, it is clear that states have jurisdiction to prosecute persons who have committed crimes whilst present on their space objects, i.e. in the space crafts, space vehicle, or in their respective module of the ISS. For example, if the spacecraft was registered in State A, then State A can exercise its power and control over the spacecraft, including its nationals, i.e. against the astronaut of its nationality, or against another astronaut from another nationality as long as the crime took place in State A's spacecraft.

In summary, jurisdiction in outer space can be classified into space jurisdiction in outer space and state's jurisdiction over its space objects and personnels. Specifically, the differents between these two jurisdictions are based on location, objects and nationality.

\section{THE INTERNATIONAL SPACE STATION}

From the early 1970 s until today, several definitions have been suggested to define the space station. For example, Smith defined the space station

$24 \quad$ See Article 7, Treaty on Principles Governing the Activities of States in the Exploration and Use of Outer Space, including the Moon and Other Celestial Bodies 1967.

25 See Article 12(1), Agreement Governing the Activities of States on the Moon and Other Celestial Bodies 1979. 
as a facility, manned or unmanned, larger than a conventional satellite and located in outer space. ${ }^{26}$ The author also suggests that the space station is intended for a relatively long-term period of use. ${ }^{27}$ According to the National Aeronautics and Space Administration (NASA), the current space station, the ISS, is larger than a six-bedroom house, consists of several pressurized modules where a crew of seven astronauts can live and conduct scientific experiments. ${ }^{28}$ Dunk found that the ISS is similar to a state because of its large, complex structures and manned space objects. ${ }^{29}$ According to the European Space Agency (ESA), the ISS is a co-operative programme between Europe, the United States, Russia, Canada, and Japan. The European Agency also asserted that the purpose of the ISS is for the joint development, operation and utilisation of a permanently inhabited space station in low-earth orbit.

\section{The Legal Framework in the International Space Station}

According to the ESA, the legal framework of International Space Station is built on three levels of international co-operation agreements: ${ }^{30}$

1. The International Space Station Intergovernmental Agreement (IGA): ${ }^{31}$

2. Four Memoranda of Understandings (MoUs) between the National Aeronautics and Space Administration (NASA) and each four co-operating Space Agency with European Space Agency (ESA), Canadian Space Agency (CSA), Russian Federal Space Agency (Roscosmos), and Japan Aerospace Exploration

26 Delbert D Smith, Space Stations: International Law and Policy (Colorado: Westview Press, 1979), 1.

27 Smith, Space Stations: International Law and Policy.

28 "Space Station Extravehicular Activity," accessed October 10, 2014, http:// spaceflight.nasa.gov/station/eva/index.html.

29 Frans G von der Dunk, "Pandora's Box? The Basic Legal Framework for Doing Business with a Space Station: An Inventory of Problems," Space and Telecommunications Law Program Faculty Publication, no. 2 (1991).

30 "International Space Station Legal Framework." European Space Agency (ESA), accessed July 3, 2014, http://www.esa.int/OurActivities/Human_Spaceflight/ International_Space_Station_legal_framework.

31 Ibid. According to the European Space Agency, The International Space Station Intergovernmental Agreement, or commonly known as IGA was signed on 29 January 1998 by the fifteen governments involved in the Space Station project. The IGA aims to provide for 'a long term international cooperation, for the detailed design, development, operation, and utilisation of a permanently inhabited civil Space Station for peaceful purposes in accordance with international law.' 
Agency (JAXA); ${ }^{32}$ and 3. Various bilateral Implementing Arrangements. ${ }^{33}$

The International Space Station Intergovernmental Agreement (IGA), works like an umbrella framework regulating the ISS. ${ }^{34}$ One of the main provisions of IGA is regarding the jurisdiction and control over its elements and personnels. Article 5(2) of the IGA provides "... each partner shall retain jurisdiction and control over the elements it registers... and over personnel in or on the space station who are its nationals. ${ }^{35}$

With respect to criminal offences on the space stations, article 22(1) of the IGA allows the partner States to assert their criminal jurisdiction over personnels in the territorial limits of a state's criminal jurisdiction in the ISS. The provision states that, "partner States may exercise criminal jurisdiction over personnels in or on any flight elements who are their respective national." This provision permits the partner States to retain their jurisdiction and control over their registered elements and over personnels in or on the Space Staion who are their nationals. This means, the provision allows for the partner States to apply their national laws including their national courts in criminal matters. Furthermore, this provision also confers on the partner States the power to punish their accused nationals irrespective of where the perpetrators are located, whether in its element or in another partner's elements. ${ }^{36}$

However, article 22(2) permits an aggrieved state to exercise criminal jurisdiction where the perpetrator's state fails to prosecute the perpetrator. Article 22(2) of the IGA states that: ${ }^{37}$

A case involving misconduct on orbit that: (a) affects the life or safety of a national of another Partner State or (b) occurs in or on or causes damage to the flight element of another Partner State, the Partner State whose national is the alleged perpetrator shall, at the request of any affected Partner State, consult with such State concerning their respective prosecutorial interests. An affected Partner State may, following such consultation, exercise criminal jurisdiction over the

32 Ibid. The objective of the MoUs between the four space agencies is to assist the IGA by ensuring that the aims of the IGA are effectively executed.

33 Ibid. The Arrangements assist to implement the Memoranda of Understanding (MoU) by specifiying guidelines and tasks among the partner States.

34 von der Dunk, "Space Law in the Age of the International Space Station."

35 Article 5(2), International Space Station Intergovenmental Agreement 1998.

36 Julián Hermida, "Crimes in Space: A Legal and Criminological Approach to Criminal Acts in Outer Space," in Proceedings of the Forty-Eighth Colloquium on the Law of Outer Space, 2006, 156-77.

37 See Article 22(2), Intergovermental Agreement 1998 (IGA). 
alleged perpetrator provided that, within 90 days of the date of such consultation or within such other period as may be mutually agreed, the Partner State whose national is the alleged perpetrator either:

(1) concurs in such exercise of criminal jurisdiction, or

(2) fails to provide assurances that it will submit the case to its competent authorities for the purpose of prosecution. ${ }^{38}$

The provision permits an aggrieved State to exercise criminal jurisdiction where the perpetrator's state fails to prosecute the perpetrator. ${ }^{39}$ Thus, following from article 22(2) of the IGA, it appears that this provision applies the principle of 'passive personality' under the international law. ${ }^{40}$ This is because the passive personalty principle recognises the nationality of the victim, thus a State can assert laws that apply to try a foreign national who commits crimes against the State's nationals outside the State's territory. ${ }^{41}$

It is clear that the IGA's approach to conflicting jurisdiction is premised on two principles of jurisdiction. First, jurisdiction that is based on nationality of the offender; and second, jurisdiction that is based on the passive personality principle otherwise known as jurisdiction based on the nationality of the victim. The adoption of both principles of jurisdiction by the IGA is a clear evidence that proves that the principles of international law still prevail even in the space station.

\section{CURRENT ISSUES}

Article 1 of the IGA states that the ISS, apart from being the center for scientific research and studies, also serves commercial purposes. ${ }^{42}$ Consequently, the utilisation of the ISS for commercial purposes

38 Ibid.

39 Werner Balogh. "Astronauts and Space Tourism: Special Legal Issues of the use of Outer Space Technologies." Lecture, University of Vienna, Austria, 2009. Accessed May 13, 2014, http://homepage.univie.ac.at/werner.balogh/ pdf/Special\%20Issues\%20WS2009-2010/Astronauts $\% 20$ and $\% 20$ Space $\% 20$ Tourism\%20REV2_18012010.pdf.

40 Dunk, "Space Law", 154.

$41 \quad$ See United States v. Yunis. 681 F.Supp. 896. In this case, a Lebanese hijacker was arrested and imprisoned by the United States for hijacking a Jordanian airlines in June 1985. The nexus between the United States with the Defendant was the presence of the U.S nationals on board the hijacked plane by the Defendant. The U.S court convicted the Defendant based on the passive personality principle and ruled that the application of this principle was appropriately used.

42 Article 1 of the IGA reads "...This civil international Space Station will enhance the scientific, technological, and commercial use of outer space." 
may lead to an increase in space tourism, and thus the potential for a greater degree of social contact among people living and working in outer space. ${ }^{43}$ Gorove found that it is possible for crimes to happen in outerspace. He further found that there are four areas in space where a crime might occur. First, in void; second, on board a spacecraft, space laboratory or another space object in outer space; third, on such craft or on a celestial body; and fourth, on a celestial body but not aboard such craft either within a particular facility or without it. ${ }^{44}$

The jurisdiction based on nationality approach adopted by the IGA presents some flaws. The IGA does not specify how the problem of concurrent jurisdiction will be solved. Gorove analysed the flaws of the IGA, and found that one of the flaws is the conflicts in concurrent jurisdictions between Partner States to the ISS. Gorove presents a situation where, for instance, a Japanese national has committed a crime in an 'element' belonging to Canada. According to the territorial principle adopted by the Outer Space Treaty 1967, Canada would have jurisdiction to prosecute the Japanese national. According to the nationality principle adopted by the IGA, Japan would also have jurisdiction to prosecute its national. Thus, in such a case, both nations would have jurisdiction to prosecute the individual. Another scholar, Hermida, found that even though the 'nationality principle' affords a right to the perpetrator's state to prosecute its national, simultaneously, it also gives the right to that state not to exercise its jurisdiction over its national. ${ }^{45}$ Consequently, it pre-empts the right of the aggrieved state to prosecute. ${ }^{46}$ According to Article 22(2) of the IGA, the aggrieved state may only prosecute the perpetrator if the perpetrator's national government has failed to exercise its jurisdiction to prosecute them. As a consequence of this nationality principle, there will be a trust issue between the two nations as both would prefer the perpetrator to be tried and prosecuted under its own national laws and national tribunals.

If the International Space Station (ISS) were to be commercialised, a conflict could arise where a non-State partner were to seek jurisdiction to try the offender. ${ }^{47}$ That is contrary to the $\mathrm{IGA}^{48}$ and to the 1979 Moon Agreement itself. Another interesting issue that arises in the context of

\footnotetext{
43 Stephen Gorove. "Developments in Space Law: Issues and Policies." International Lawyers 6, no.2 (The Netherlands: Martinus Nijhoff Publishers, 1991): 325-324.

44 Ibid.

45 Ibid., 405.

46 Hermida, "Crimes in Space: A Legal and Criminological Approach to Criminal Acts in Outer Space."

47 Jason Krouse. "Making Space Law Matter." American Bar Association Journal (2008), accessed October 11, 2014, http://www.heinonline.org.

48 Ibid.
} 
a crime committed in the space station is where the perpetrators of the crime are a gang who are made up of people of different nationalities, and involving victims from multiple states. Similarly, where the alleged perpetrator or the aggrieved victim is not from a State that is a partner to the ISS. Clearly, the missing element here is to what extent does a State has criminal jurisdiction in the ISS, when they are not a partner to the IGA. ${ }^{49}$

Blount examines the issue of national jurisdiction in outer space..$^{50}$ The author asserts that space law is not sufficient to address the participation of private entities in space activities. The present space law has a limited scope in determining the correct principles of jurisdiction applicable to outer space. Blount also found that it is questionable whether a state can assert its criminal jurisdiction in circumstances in which the alleged offender or victim is a space tourist from a State that has not acceded, signed or ratified the Outer Space Treaties, or the State has no domestic laws to regulate space activities. ${ }^{51}$ Even though under the Convention on Registration of Objects Launched into Outer Space (the Registration Convention), the 'State of Registry' has jurisdiction to prosecute individuals who commit crimes on space objects that are registered with that State irrespective of the nationality of the offender, there is reason to be skeptical that a state whose national has committed a crime, would submit its national over to the jurisdiction of the 'State of Registry', when it has never ratified or acceded to the Space Law Treaties.

In October 2007, Malaysia sent its first astronaut, Datuk Dr. Sheikh Muszaphar Shukor Al Masrie bin Sheikh Mustapha to the ISS aboard the Russian Soyuz TMA-11. Malaysia has no domestic legislation to govern criminal conflict arising in outerspace. Malaysia is neither a partner state to the IGA nor has the power to invoke the territorial jurisdiction that is conferred on signatories to the Outer Space Treaty 1967 with the status of a State of Registry. Hence, it is unclear if Malaysia has any jurisdiction over crimes involving its nationals that occur in outer space. Nevertheless, it is recommended for Malaysia to enter into a specific agreement with respect to criminal jurisdiction and legal enforcement with the Partner State to ISS, prior to any Malaysian space personnel or

$49 \quad$ Article 6(4) of the Intergovernmental Agreement (IGA) clearly prohibits any ownership of equipment in the ISS or to own an element of the partner State to the ISS, without prior notification to the other partner States. From this provision, assuming that a non-partner State to the ISS may own any equipment or element in the ISS provided if the partner States consented to it.

50 P.J. Blount. "Jurisdiction in Outer Space: Challenges of Private Individuals in Space." Journal of Space Law 33 (2007): 299-340.

$51 \quad$ Ibid. 
private entity boarding the space station. Alternatively, Malaysia may also request for the foreign offender to be extradited from his country to Malaysia and consequently be tried in Malaysia.

\section{RECOMMENDATIONS}

As there are flaws in the space laws and in the IGA with regard to the nationality principle and the missing element in respect of the non-partner states, States may have recourse to other sources of International Law to assist the state's criminal jurisdiction in the commercial space station. Article 38 of the Statute of the International Court of Justice laid down four sources of International Law that may be of great assistance. Apart from that, 'soft laws' like Resolutions, Memoranda of Understandings ('MoUs'), Codes of Conduct, and declarations may also be good alternatives, especially when it is impossible to strictly observe the "hard laws'.

Another possible solution is for the State to enter into a separate agreement with the respective Partner States to the International Space Station. Article 2 of the Registration Convention 1976 states that:

where there two or more launching States in respect of any such space object, they shall jointly determine which one of them shall register the object in accordance with paragraph 1 of this article, bearing in mind the provision of article 7 of the Treaty of Principles Governing the Activities of States in the Exploration and and Use of Outer Space, including the Moon and Other Celestial Bodies, and without prejudice to appropriate agreements concluded or to be concluded among the launching States on jurisdiction and control over the space object and over any personnel thereof.

In other words, the space law does honors any agreement concluded between States to exercise their criminal jurisdiction and control.

States may also request for extradition of the foreign criminal offender. Extradition is a common practise because a State may request from another State to surrender its national to the former State for trial and punishment. However, to resort to extradition, the presence of a legal treaty between States is significant because such agreement would govern the process and the procedures of extradition that should be observed by both States.

Finally, it is also strongly recommended for States to ratify all five space treaties and begin constructing their own national space laws. 
Even if a state has ratified the relevant space treaties, in the absence of the state's own national space legislation, it may be impossible for the state to invoke its jurisdiction. ${ }^{52}$ This is because, the national space law will not just regulate their national space activities, but simultaneously will ensure that the state will observe that such space activities comply with the international space law. ${ }^{53}$ Perhaps the most radical recommendation is for the current space treaties to be amended to cater for the growing complexity of issues in the era of space commercialisation.

In summary, despite the flaws in the space treaties and the IGA, Public International Law does provide a few solutions in respect of crimes in outer space. States may resort to prior binding agreements with regard to criminal jurisdiction or demand for the extradition of the foreign offender. Similarly, soft laws may be another option to assist in any jurisdictional dispute.

\section{CONCLUSION}

This paper raises some pertinent issues relating to criminal jurisdiction of states in space law and disucsses some emerging issues. In particular, the paper has focused on the limits of a State's criminal jurisdiction in outer space. There are a few important points that have emerged from this analysis. First, although outer space law clearly prohibits States from claiming sovereignty rights over parts of outer space, it however confers jurisdictional powers to States in respect of its space objects and personnel. The law also recognises the State of registry, allowing states to prosecute both their nationals and whoever has committed a crime on a space object that is registered to that State. Second, although the territorial principle is a primary principle of space law, with respect to a State's criminal jurisdiction to try individuals who commit crimes whilst aboard the ISS, the nationality principle is literally invoked as embodied in the IGA. Finally, the IGA only confers the power to govern and regulate activities in the ISS on the Partner States. Thus, States who are not party to the IGA have to resort to other solutions to bring the criminal offender to justice. Nevertheless, despite the flaws in the IGA and in the space law generally, the principles of International Law still prevails while protecting the rights and interests of an individual and a State even vertically up to outer space.

\footnotetext{
$52 \quad$ Imgard Marboe, "The Importance of National Space Legislation for the Peaceful Uses of Outer Space" (Vienna: University of Vienna), accessed September 30, 2015, http://www.unoosa.org/pdf/pres/lsc2013/symp2-02E.pdf. Ibid.
} 